\title{
O DEBATE SOBRE A DIALÉTICA HOJE
}

\author{
Manfredo Araújo de Oliveira*
}

SINTESB - 0 artigo tematiza a controvérsia contemporânea a respetto da estrutura e da legitimidade da dialética enquanto discurso humano. No contexto atual deste debate se articulam duas tendências interpretativas da estrutura da dialética: a que vincula a dialética ao mundo vivido, cuja racionalidade se distancia profundamente da ractonalidade vigente nas ciências modemas, aproximando-se da hermenêtutica ou da retórica. Uma segunda direçāo interpreta a dialética enquanto reflexão transcendental, em última inståncia, como a lógica de uma filosofia do absoluto, ou seja, como o procodimento especifico da reflexão filosofica enquanto tal.

PALAVRAS-CHAVB - Dialética, controvérsia contemporànea, mundo vivido, reflexâo transcendental.

\begin{abstract}
The article presents the contemporary controversy regarding the structure and legitimacy of the dialectic while human speech. In the current context of this debate two interpretative tendencies of the structure of the dialectic are articulated: the one that links the dialectic to the lived world, whose rationality goes away deeply of the effective rationality in the modern sciences, approaching of the Hermeneutic or of the Rhetoric. A second direction interprets to dialectic while transcendental reflection, uitimately as logic of a philosophy of the absolute, that is to say, as the specific procedure of the philosophical while such refection.

KEY WORDS - Dialectic, contemporary controversy, lived world, transcendental reflection.
\end{abstract}

A idéia da dialética como discurso rigoroso, racionalmente legitimado, se tornou objeto de grandes controvérsias. Tudo leva a crer que a dialética, de repente, não sabe mais o que é. Tornou-se, assim, uma das exigências de nosso tempo atingir clareza sobre a estrutura e a legitimidade da dialética enquanto discurso humano e, mais ainda, de seu lugar na filosofia. A partir dos anos setenta vem acontecendo este debate, com a participação de diferentes pensadores e com diferentes respostas. Nesta exposição, é sugerido um horizonte de compreensäo desta discussão a partir da distinção de duas grandes tendências básicas na solução das questões levantadas: uma primeira tendência interpreta a dialética enquanto uma racionalidade que encontra suas raízes no próprio mundo vivido e emerge como um discurso diferente e alternativo ao modelo de racionalidade que toma a ciência moderna como padrão e se entende como razão fraca, isto é, como razão vinculada a condições de finitude. Uma segunda vai interpretar a dialética como radicalização da reflexão transcendental, ou seja, como a lógica de uma filosofia do Absoluto, portanto, como razão forte. Levaremos, em consideração,

* Professor Titular da Universidade Federal do Ceará - UFC.

\begin{tabular}{|l|l|l|l|l|l|}
\hline VERTTAS & Porto Alegre & v. 43 & $n^{0} 4$ & Dezembro 1998 & p. 897-925 \\
\hline
\end{tabular}


nesta exposição, dois exemplos de cada uma das tendências. Uma pergunta vaí surgir, espontaneamente, neste contexto: é possivel e necessária uma síntese entre as duas interpretações?

\section{1 - A Dialética enquanto Práxis dialógica}

\section{1 - A Escola de Bruxelas: a Dialética enquanto Retónica}

Para Chaïm Perelman, a discussão sobre a dialética tem a ver com a determinação da natureza mesma do pensamento filosófico e é a grande oportunidade para articular uma forma de pensamento que se contrapõe a tudo o que, na história do ocidente, pretendeu ser filosofia primeira, o cerne da tradiçăo filosófica ocidental. Para ele, fllosofia primeira é qualquer tipo de pensamento metafisico, que levanta a pretensåo de estabelecer princípios primeiros enquanto princípios do ser (ontologia), do conhecimento (epistemologia) e da ação (axiologia), enquanto prinćpios, absolutamente, fundamentais, de que tudo mais depende e que são pressupostos inelimináveis de toda a vida humana, portanto, também, de sua contestação. Neste sentido, trata-se de principios simples, evidentes, racionais, absolutos, categorias necessárias do espirito humano. Na forma moderna de filosofia transcendental, o filósofo tenta mostrar, através de uma reflexão do pensamento sobre si mesmo, que seus adversários, já sempre, trabalham pressupondo, implicitamente, estes princípios, que, por isto, se revelam como inabaláveis.

Nesta perspectiva, toda a direção do pensamento será orientada a partir de um ponto inicial constituído por uma realidade necessária, por um conhecimento evidente ou um valor absoluto. Situa-se, aqui, na esfera do a priori e nenhuma experiência poderá modificar estes princípios, portanto, trata-se de um conhecimento perfeito, necessário e absoluto. Antes da descoberta destes princípios, estes filósofos se encontram numa dúvida absoluta, numa arbitrariedade completa, sem nenhum guia. Depois da adesão, têm certeza plena, o que significa dizer que eles oscilam entre o ceticismo e o dogmatismo, entre a arbitrariedade completa e a necessidade inelutável, que os constrange inteiramente. Por esta razão, aqui, uma crise de fundamentos è catastrofal. Ora, a história do pensamento ocidental é a história da concorrência entre as filosofias primeiras incapazes, pois cada uma tem pretensões absolutas e excludentes, de encontrar uma linguagem comum.

A dialética, neste contexto, vai emergir como uma postura de sentido inverso a toda filosofia primeira, ou seja, como filosofia regressiva, que considera seus axiomas, seus critérios e suas regras não, como no caso das filosofias primeiras, como critérios de necessidade, de evidência ou de imediação, a verdade primeira posta na base do sistema, mas vai situá-los na esfera da facticidade, portanto do a posteriori e sua evolução e, por isto, dotados de uma validade que é medida pelos fatos que permitiram pô-los à prova, ou seja, eles possibilitam um conhecimento imperfeito e sempre perfectivel, ${ }^{1}$ marcado por imprecisão, equivocos e confusão de

1 Cl.: Perelman Ch, Retóricas, Săo Paulo, 1977, p. 9: “A intervençăo do juiz de última instância permite, em direito, encerrar o debate, graças à autoridade da coisa fulgada. A fllosofia năo concebe tamanha autoridade; é por essa razăo que o debate sempre pode ser recomeçado e continuado indefinidamente". 
noçōes, cujo sentido não pode ser considerado imutável e fixado uma vez para sempre. Seu ideal năo é de perfeição, no sentido da aproximação da alguma plenitude última, mas de progresso permanente enquanto possibilidade de solucionar dificuldades que se apresentam através de julgamentos provenientes de uma discussầo entre pessoas de mente livre em interação umas com as outras, ${ }^{2}$ o que conduz a uma tomada de posiçăo. Para a filosofia dialética, há princípios em desuso que, já foram, universalmente, aceitos e, depois, tiveram ser abandonados; por isto, para ela uma crise de fundamentos é benéfica, pois significa uma confirmação de suas teses básicas e um aprofundamento do pensamento humano e, assim, ela é uma das caracteristicas de épocas de reviravolta, de crise e de instabilidade.

As filosofias primeiras e a filosofia regressiva têm um objeto comum: o estudo do estatuto das proposiçōes fundamentais concernentes ao ser, ao conhecimento e à ação e as divergências se situam na compreensão do que seja fundamental. Para a metafisica, trata-se de algo, absolutamente, primeiro, pressuposto por tudo mais, de uma esfera de validade, que é anterior à esfera dos fatos. Trabalha-se, aqui, com um conceito não-empírico, absoluto de razão, ${ }^{3}$ de lógica, cujas regras são inexoráveis e coercivas. Apela-se para uma intuição, uma evide̊ncia, portanto, um fato psicológico, para justificar a validade universal, incondicional e absoluta do conteúdo desta evidência ${ }^{4}$ e, assim, transformam-se princípios, que, na realidade, são contingentes, em princípios eternos. Trata-se de um raciocínio por analogia: a estrutura lógica da fundamentação das proposiçōes fundamentais é a mesma das proposições derivadas, ou seja, ela ocorre através da vinculação a algo anterior, no caso, a intuição ou evidência à qual se confere o valor de um critério absoluto. A tarefa básica da filosofia primeira consiste em buscar estes elementos definitivos e perfeitos, a base invariável e eterna do sistema metafisico. ${ }^{5}$ Ela é, sempre, uma teoria do ser perfeito, fundamento de toda realidade.

Ora, o que é perfeito é, em princípio, imperfectivel independentemente de qualquer experiência posterior, de qualquer descoberta nova, portanto, válído, universalmente, para além das contingências da história, da historicidade de todo saber, já que tínhamos a ver com um conhecimento eterno. O grande problema neste contexto é explicar a emergência do desacordo, do erro, numa palavra, a

2 Neste sentido de uma dialética que recuperaria seu sentido originário, que se refere à arte do diálogo e constituiria um tipo de fllosofia intéramente diferente do que a tradiçâo conheceu. Cf.: Perelman Ch, Retóricas, op. cit., p. 10: "Tratar-se-ia então de uma dialética que nâo concuziria necessariamente a uma finalidade preexistente, mediante um desenvolvimento uniforme e necessário, mas que deixaria certo espaço à liberdade humana, com suas possibilidades de transcender qualquer sistema, qualquer totalidade dada".

Cf: Pereiman Ch., Retóricas, op. cit., p. 183: "Tradicionalmente, o discurso filosófico é um discurso que se dirige à razão, sendo esta considerada uma faculdade fluminada pela razão divina ou, pelo menos, modelada por esta, faculdade intemporal e invariável, comum a todos os seres racionais, e que constitui a caracteristica especifica de todos os membros da espécie humana.

4 Cf: Perelman Ch., Retóricas, op. cit., p. 180-181: "I...] as fllosofias clássicas nào se interessaram muito por seu auditório e, a fortiori, não fazem muito esforço para adaptar-se a este [... ] o recurso a idétes intemporais e universais, tais como a verdade, a razdo e a evidéncia, permite dispensar a adesâo efetiva do auditório".

Cf.: Perelman Ch, Retóricas, op. cit., p.183: "A busca de tais proposiçðes evidentes - e a vinculaçäo a estas por meio de demonstraçč́es, de todas as proposições duvidosas - parece assim a tarefa filosófica por excelência, a que permitiria aos homens comungar nas mesmas verdades". 
questão é saber como do absoluto é possivel derivar o relativo, do perfeito $0 \mathrm{im}$ perfeito, da ordem a desordem. A saída vai ser, sempre, a introdução de um segundo elemento para explicar o desvio: o subjetivo oposto ao objetivo, a imaginaçăo à razão, o prazer ao dever, a matéria ao espírito, etc. 0 monismo inicial desemboca num dualismo que vai levantar um problema novo: como explicar as relaçōes entre estes dois universos, a contingência e a evolução deles.

O fracasso da metafísica se deveu, principalmente, a duas razōes: antes de mais nada, à incapacidade de se chegar a uma acordo sobre o que deveria ser considerado evidente e necessário. A metafisica, em virtude disto, oferece o espetáculo de uma pluralidade de dogmatismos opostos. Em segundo lugar, sobretudo os especialistas em filosofia, censuraram a incapacidade das filosofias primeiras de construir um sistema coerente a partir dos principios estabelecidos. A reação à metafisica provocou o aparecimento de filosofias antimetafisicas, que têm uma postura, puramente, negativa: negam a existência de qualquer absoluto, qualquer incondicional, qualquer princípio primeiro, freqüentemente, na base da pressuposição de outros princípios primeiros.

$\mathrm{Na}$ perspectiva da filosofia regressiva, o fundamental é, também, um fato, talvez mais importante do que outros, mas, sempre, contingente. Por isto, seus princípios năo adquirem sua validade a partir de uma evidência ou intuição privilegiada, mas através das consequiências que deles se podem tirar e que nada mais são do que os próprios fatos que servem de ponto de partida para a filosofia.

Para Perelman, encontram-se na filosofia regressiva os mesmos principios ${ }^{6} \mathrm{da}$ dialética de Gonseth: 1) O princípio da integralidade: a filosofia deve levar em consideração a totalidade da experiência e coordenar esta experiência de tal modo que possa emergir uma solidariedade intima entre os fatos. Este principio afirma o caráter sistemático da filosofia; 2) 0 princípio da dualidade: trata-se de não esquecer que toda construção filosófica é um sistema inacabado e imperfeito. 0 pensamento é, em princípio, aberto e a discussão é elemento essencial para seu desenvolvimento. A rejeiçăo deste princípio implicaria eliminar, do universo, toda imprevisibilidade, toda contingência, toda liberdade que däo significado ao tempo e à história; 3) O principio da revisabilidade: nenhuma proposição do sistema se encontra, a priori, isenta de uma possibilidade de revisão. A rejeição deste princípio significaria um retorno à metafísica; 4) O princípio de responsabilidade: o elemento determinante na elaboração do sistema é a decisão avisada do filósofo. Neste sentido a dialética não é um mecanismo automático ou arbitrário de pensamento, mas uma conquista de uma mente consciente de seu esforço e de sua responsabilidade. É este elemento que introduz um elemento humano na obra filosófica.

No entanto, não se trata de uma escolha arbitrária, mas mediada por argumentos, cujo valor o próprio filósofo pode avaliar e a lógica que subjaz a esta escolha é uma lógica, já, examinada por Aristóteles, que é uma lógica que não trata do verdadeiro, mas do preferivel, isto é, a retórica. ${ }^{7}$ Só a retórica ${ }^{8}$ permite com-

Cf.: Perelman Ch., Retónicas, op. cit., p. 140 e ss.

7 Cf.: Perelman Ch./Olbrechts-Tyteca L., Tratado da argumentaçăo. A nova retórica, São Paulo, 1996, p. 20 e ss. 
preender a aplicação do princípio de responsabilidade: nesta esfera, os argumentos influenciam o pensamento, mas não impõem a adesão a eles. Na metafísica, o procedimento argumentativo pretende demonstrar princípios necessários sobre os quais o filósofo não dispōe; aqui, ao contrário, ele é o juiz sobre os próprios fundamentos. Por esta razão, o modelo da filosofia não é a matemática, nem as ciências, mas a atividade dos juristas.

Para Perelman, só com este modelo se pode rejeitar o cético, puramente, negativo, que repele todo critério absoluto e, portanto, se recusa a tomar uma decisão por falta de critério. Tanto o dogmatismo como o ceticismo se opõem ao princípio dialético da responsabilidade, porque, ou por buscar um princípio necessário ou por rejeitar qualquer um, convergem ambos em negar a liberdade do pensador. O filósofo dialético escolhe, ponderadamente, sua atitude, embora sua escolha, ainda' que regida por regras, ${ }^{9}$ jamais, seja necessária: ele, nunca, parte do nada, mas de um conjunto de fatos contingentes, mas, suficientemente, seguros para que neles ele possa radicar sua reflexão. O filósofo dialético recusa, por isto, qualquer princípio absoluto, que só pode levá-lo a um regresso ao infinito, sem nenhum sentido e sem direção. ${ }^{10}$ Antes ele defende a idéia de uma permanente revisão de seus conceitos e dos princípios da teoria de onde parte para que se torne possivel um melhor conhecimento dos fatos e, portanto, um aprofundamento de seu pensamento. Inclusive deverá recusar seus principios se houver razões suficientes para isto, uma vez que não reconhece nenhuma evidência imune de critica. ${ }^{11}$

No entanto, uma objeção fundamental poderia emergir aqui: a filosofia dialética não pressupõe, implicitamente, o que nega, ou seja, a existência de princípios incontestáveis? O próprio princípio de integralidade não pressupōe a coerência do pensamento e, por isto, o principio de não-contradição como principio, universalmente, válido? Para Perelman a única saída possivel a esta situação, já que é impossivel negar a existência de princípios tanto na esfera da razão teórica como da razão prática, é considerá-los de natureza, puramente, formal. Assim, por exemplo, o princípio de năo-contradição é um principio universal, mas depende, para sua interpretaçăo e aplicação do sentido que se dá às palavras proposição verdade e falsidade.

8 Cf.: Perelman Ch., Retóricas, op. cit., p. 70: "A retórica, em nosso sentido da palavra, difere da lógica pelo fato de se ocupar năo com a verdade abstrata, categórica ou hipotética, mas com a adesăo".

9 O grande erro da tradiçăo consistiu em interpretar a dialética platônica como um esboço de sistema dedutivo. Assim, o método dialético, que, na realidade, é o correspondente, em nossa mente, de um pensamento dialogado, se transformou num "sistema dialético, monolítico, no qual, a partir de teses iniciais, as consequêencias se desenvolveriam de uma forma automática que năo deixariam nenhum espaço à personaltidade nåo só de quem responde, mas do próprio dialético. Dia'ética e lógica analitica coincidiriam". (Pereiman Ch., Retóricas, op. cit., p. 49).

10 Precisamente, aqui, se sttua, para Perelman, a diferença entre analitica e dialética. Uma vez estabelecidos os princípios, o método dedutivo trata de expor os resultados dai decorrentes. A dialética é a única maneira de raciocinar sobre os próprios principios das ciências em formação, o que, só, é possivel na forma do diálogo. Portanto, o método dialético, enquanto heuristico e critico é inevitavelmente associado ao pensamento dialogado. Cf.: Perelman Ch., Retóricas, op. cit., p. 49-50.

11 Cl.: Perelman Ch., Retóricas, op. cit., p. 53: "Por isso, o método dialético è, por excelência, o método de toda filosofla que, em vez de se fundamentar em intuiçôes e evidências, consideradas irrefragáveis, dá-se conta do aspecto social, imperfeito e inacabado do saber filosófico". 
Por outro lado, a filosofia dialética se encontra diante de um desafio desconhecido na tradição: sua área é a do contingente, do relativo, do aparente e do fato. Ela consegue trabalhar bem a questão do ser humano e de sua liberdade, do temporal e do histórico. No entanto, para poder dar conta da totalidade da experiência ele teria que dar espaço, também, ao normativo, ao real, ao absoluto e necessário. Não necessariamente uma filosofia dialética estaria obrigada, a partir de sua postura, a deduzir o direito do fato ou a realidade da aparência. Claro que 0 direito e a realidade são, também fatos, mas de natureza, totalmente, diferente. Então, é tarefa de uma filosofia dialética repensar estas oposições tradicionais, tornando-as relativas, mas sem fazê-las desaparecer como se fossem fruto da imaginação metafísica e esta tarefa é permanente, porque o futuro permanece, sempre, aberto à experiência do imprevisivel.

\section{2 - Rüdiger Bubner: A Dialética enquanto "Tópica"}

\subsection{1 - Os pressupostos dialogais da Dialética: Dialética e Finitude}

A questão da dialética, para Bubner, é, em primeiro lugar, uma questão de concepção de racionalidade e, com isto, de tomada de posição em relaçăo ao que é hegemônico em nossos dias: hoje, pensa-se racionalidade a partir do modelo de conhecimento vigente na ciência, o que, para Bubner, é um grande reducionismo. ${ }^{12}$ É importante superar esta situação e a dialética é o camínho adequado para isto na medida em que ela é entendida a partir do que Aristóteles denominou de "Tópica", que é uma racionalidade imanente ao próprio mundo vivido. ${ }^{13}$ No correr da história do ocidente, a dialética esqueceu suas origens na práxis do mundo vivido e se entendeu, cada vez mais, como método, o que se plenificou no pensamento de Hegel, que levantou a pretensăo de desligar, completamente, a dialétíca da práxis do mundo vivido a fim de autonomizar a dialética como ciência, ou seja, enquanto um método especulativo abrangente. ${ }^{14} \mathrm{~A}$ tarefa especifica da Fenomenologia do Espirito, enquanto preparação sistemática do sistema, consistia, precisamente, em interpretar as condiçōes históricas da emergência da filosofia dialéti-

12 Esta posiçăo pretende pensar a racionalidade fora do processo de sua conquista, o que, para Bubner, nåo passa de uma flusăo. Por exemplo, o sistema enciclopédico da filosofia, a sociedade de sujeitos livres, a ciência unificada insuperável, tudo isto é paradigma do uma definitividade, onde a idéla de racionalidade estaria, plenamente, realizada. No entanto, năo se pode determinar a racionalidade a partir do fim de um processo, que nâo conhecemos, mas antes devemos pensá-la a partir das pressuposiç̄̄es que nos conduzem ao processo, ou seja, a partir do mundo vivido. Cf.: Bubner R, Dialektik als Topik. Bausteine zu einer lebensweltlichen Theorie der Rationalităt Frankfurt am Main, 1990, p.111.

13 Normalmente, segundo Bubner, a Dlalética de Platăo é apresentada como o modelo deste processo de metodologizaçăo. No entanto, para Bubner, só, se pode afirmar isto, quando se para na doutrina das Idéias, o que, em Platāo, de forma alguma, constituf o fim último da dialética. O que ela, de fato, pretende é chegar à Idéia do Bem, que é a presentificaçäo do fim último de todo o trabalho dialético. A Idéia do bem faz a mediaçăo da Teorla com a Práxis de modo que o fim da dialética năo pode consistir em sua perfeiçấo metodológica, mas seu sentido é a aprendizagem e a aplicação do procedimento correto da fala e isto, só, pode ocorrer na esfera do mundo vivido. $\mathrm{Cl}$ : Bubner R., op. cit., p. 80-82.

14 Segundo Bubner, a tarefa própria à dialética é explicitar a orientaçâo originária para o bem que subjaz e antecede toda e qualquer conhecimento cientifico. Cf.: Bubner R., op. cit., p. 82. 
ca como formas de manifestação do espírito. Em princípio, nada deve permanecer que vincule o sistema dialético-especulativo a condiçōes que provêm do mundo pré-filosófico, pois isto prejudicaria a conceituação, metodologicamente, auto̊noma..$^{15}$ No fim da Fenomenologia, com o saber absoluto, atinge-se o nivel em que a lógica, fundadora do sistema, pode constituir-se.$^{16} \mathrm{~A}$ construçăo, propriamente, do sistema coincide com a pureza do desenvolvimento conceitual lógico ${ }^{17}$ e é conseqüência de um método que de tal modo se libertou de seus pressupostos que pode construir, sozinho, seu próprio caminho. Aqui não se recorre mais a fatos; ${ }^{18}$ ao contrário, o método é autônomo na medida em que, sem interrupção, é capaz de reproduzir a coisa em seu desenvolvimento imanente.

O propósito de Bubner é se contrapor a este processo de metodologizaçăo e cientificação da dialética e recuperar a dialética em sua dimensão pragmátíca, ${ }^{19} \mathrm{o}$ que significa, em primeiro lugar, pôr em questão a identificação, sobretudo da modernidade, entre racionalidade e método. Não só há racionalidade onde há método e, precisamente, a dialética se situa noutra esfera de racionalidade e se radica em pressupostos, que nunca podem ser, plenamente, tematizados através de procedimentos. Ela inicia, aí, onde um saber dado não vai para frente, isto é, ela, só, começa seu trabalho sob determinadas condições: já deve existir uma certa tentativa racional de enfrentar um problema que, no entanto, se mostra insuficiente. Normalmente, aparecem casos, assim, em questôes discutidas no dia-adia e, ai, emergem vários pretendentes a dar conta de algo, que se distingue de todas estas pretensōes. Antes de mais nada, é negada, aqui, a identificação entre a coisa e o ponto de vista sobre ela, justamente, a fim de que se possa respeitar a pluralidade das pretensões e para que a coisa possa ser captada enquanto tal.

$\mathrm{Na}$ medida em que a refexão é pensada a partir dos conflitos que emergem no mundo vivido, ela manifesta seu fundamento pragmático e se revela como ruptura da imediatidade, garantindo, ao mesmo tempo, o contato com a coisa. A dialética se revela, então, como unidade numa duplicídade, pois, aqui, emergem como os dois pólos de uma relaçăo, por um lado, a coisa em tela e, por outro, as diversas pretensōes. A reflexão muda a postura frente ao conteúdo, isto é, sua forma đe captação e não o conteúdo mesmo. Neste sentido coincidem reflexão e disposição a entrar num diảlogo. ${ }^{20}$

15 Esta construçäo projeta uma sequiència complexa de determinaçōes concceituais, que se originarn de um reino a priori intemo à lógica dialética. Os pensamentos, só, existem através de sua relação mútua enquanto partes de um movimento global, que desenvolve um a partir do outro na forma de solução de controvérsias dialéticas. Cf.: Bubner R, op. cit., p. 86.

16 Na medida em que a dialética se transformou num procedimento, metodologicamente, seguro e, com isto, cientificamente autõnomo, éa levanta a pretensăo de ter validade llimitada para wodo $\theta$ qualquer objeto, Cf.: Bubner R., op. cit., p. 10.

17 Para Bubner, o Husserl tardio demonstrou a flusāo desta postura na medida em que expícitou o enraizamento dos procedimentos da ciência na esfera do mundo vivido. Cf.: Bubner $\mathrm{R}$, op. cit., p. 108.

18 Cf: Bubner R., op. cit., p. 84-85.

19 Uma outra interpretaçắo da dialética enquanto pragmática, pensada na tradiçấo do pensamento analítico nos oferece Stekeler-Weithofer. Cf: Stekeler-Weihofer P., Hegels analytische Philosophie. Die Wissenschaft der Logik als kritische Theorie der Bedeutung, Paderborn, 1992. Cf.: Bubner R, op. cit., p. 15. 
Num diálogo, ocorre a desvinculação da posiçăo inicial, por um lado, e, por outro, a continuidade do interesse em relação à coisa. A capacidade decisiva, aqui, é a capacidade de relativização de posições, o que é uma decorrência do conhecimento do que seja uma posição. Ingenuamente, cada um confunde sua posição com a própria coisa e a ruptura, só, pode vir de fora através de uma outra posição, o que ocorre no diálogo. Nisto fica ciaro que se havia esquecido que a posição é uma relação: é a confrontação com a outra posição que faz a relação emergir como relaçăo. A relação, então, para com a coisa, se divide em posturas alternativas, que, mutuamente, se excluem por pretenderam dar conta da mesma coisa, enquanto esta, o comum de toda controvérsia teórica e todo conflito prático, se manifesta transcendente às posturas concorrentes. Os dois processos são, intimamente, vinculados: a negação reciproca das posiçōes e a diferença entre as posições e a coisa: esta é a estrutura subjacente tanto ao diálogo como à reflexão.

Bubner tem consciência do que fez: uma tradução, em conceitos, da experiência que perpassa a práxis do mundo vivido. Isto significa dizer que há, no próprio conteúdo da experiência, uma lógica imanente, oculta, que, precisamente, o procedimento de traduçăo explicita, quando aceito. Quem, então, entra num diálogo, através da passagem de um argumento para outro, vai enriquecer sua visăo. Quem, refletindo, enfrenta uma questão qualquer, vai realizar o mesmo processo de avaliação no confronto de um lado contra o outro. Para Bubner, este desvio é o único caminho conseqüente para o sucesso, pois aqui, ocorre, continuidade através de flexibilidade: a situação de concorrência de posturas é fundamental para 0 aprofundamento da relação à coisa, ${ }^{21}$ o que vai manifestar que a posição inicial de imediatidade era um enorme encurtamento do conhecimento da coisa, já que este, só, acontece através das relações. Só, há, propriamente, coisas onde relações são estabelecidas com ela.

Para ele, isto significa, utilizando a linguagem da metafisica, situar a dialética na esfera da Finitude, ${ }^{22}$ ou seja, situá-la fora da esfera da metafisica, pois para a metafísica a razão, em sua pureza, era a característica da infinitude, enquanto que as condições finitas da existência humana eram consideradas limitações e perturbações da razão. No entanto, para Bubner, é difícil compreender a razão que temos como uma derivação do que não temos e que, talvez, criemos por imaginação. Certamente, assim, nunca nos haveremos de entender.

\subsection{2 - O procedimento dialético}

A Dialética encontra seu lugar no processo inaugurado de confrontaçăo de pontos de vista, onde o jogo de argumentos decorre regradamente. Constitui o ponto de partida uma certa determinidade, sob que se manifesta uma coisa em tela na medida em que ela é considerada a partir de uma posição. Determinidade, por sua vez, consiste no fato de que um outro, não nomeado, é excluído a fim de fixar esta posição. Só há determinidade a partir de uma diferença não tematizada e sua tematização implica conhecimento do outro excluido. Mas a determinidade

21 Para Bubner, isto significa que a disposiçăo de começar um diálogo ou uma reflexāo pressupōe 
enquanto tal não é, ainda, elemento do processo dialético, porque, como viu Hegel, ${ }^{23}$ este começa com a superação de tais fixações e, com isto, ela relativiza a definitividade da determinidade, pois se tematiza o caráter de determinidade do determinado: é, estruturalmente, esclarecido algo que, no começo, não havia sido considerado. Na verdade, toda determinidade está numa relaçăo de oposição com uma outra e esta descoberta, já, significa superação da fixação. $O$ segundo passo é, por isto, uma tematização daquilo que é pressuposto para que possa haver determinaçāo e significa, assim, um retorno ao primeiro.

Para Bubner, é fundamental para a compreensão do que seja dialética o esclarecimento da relação do segundo passo com o primeiro. Para que possa acontecer uma determinidade no começo é indispensável que seus pressupostos não sejam tematizados, ${ }^{24}$ pois, do contrário, cairiamos numa arqueologia paradoxal, uma vez que, sempre, adiaríamos a descoberta do primeiro ponto. Em lugar nenhum se encontra o absolutamente primeiro, pois, para isto, seria necessário que, antes, tivéssemos a segurança de que, antes, nada, absolutamente, existiu e isto $\dot{e}$, facticamente, impossivel. Por esta razão, todo começo efetivo deve liberar-se das tentativas de explicitar seus pressupostos, ${ }^{25}$ do contrário, nunca, teríamos um ponto a partir de onde se pudesse começar o processo.

A dialética principia com uma situação, do ponto de vista lógico, muito especial: por um lado, temos que fazer pressupostos, que, por outro lado, precisam ser recalcados, pois o procedimento necessita de um algo a partir de onde possa começar a efetivar-se. A reflexão não traz, então, algo de, totalmente, novo, pois o que ela, propriamente, faz é explicitar o que, no primeiro momento, havia sido recalcado e que possibilitou o começo efetivo. O movimento de progresso é, assim, como diz Hegel, um retomo: retorna-se ao primeiro passo ${ }^{26}$ para explicitar seus pressupostos, ${ }^{27}$ o que manifesta a ordem necessária do procedimento.

Com isto transforma-se o objeto, porque o que, antes, era pressuposição, torna-se, agora, o próprio tema das considerações. A solidez do ponto de partida se afrouxa na medida em que se tematiza a relação pressuposta, sobre a qual ela se radica. Tematizada uma alternativa, cai por terra a cegueira de uma posição que exclui todas as alternativas, pois, assim, se confrontam dois lados com iguais direitos, uma vez que é, desta forma, que se constitui uma relação. Na medida em que os pressupostos são tematizados se toma consciência de que a relação, já sempre, esteve presente na forma da ausência, porque implícita.

23 As fixaçôes do entendimento, que imobilizam um "que" têm que ser superadas a fim de que a dialetica pcssa ter um espaço, que, precisamente, efetiva uma auto-superação de tais determinaçōes finitas. Bubner se refere, aqui, aos parágrafos 79 e ss. da Enciclopédia. Cf.: Bubner R., op. cit., p. 37.

Aqui, precisamente, se situa, para Bubner o fundamento da fixaçăo das determinidades, na medida em que permanece nảo-pensado o que é, necessariamente, pressuposto para 0 ato de determinação. Cf.: Bubner R., op. cit., p. 38.

25 Tocio começo efetivo é dependente de pressupostos que ele ainda não nomeia também. Cf.: Bubner R., op. cit., p. 39.

26 Pertencem-se, mutuamente, a determinidade do começo e a reflexão sobre seus pressupostos. Cf: Bubner R., op. cit., p. 42.

27 Pressupostos possuem um estatuto ontológico especial: eles só existem por causa das posiçóes, que deles necessitam para ser e neste ser próprio os igualmente recalcam. Cf: Bubner $\mathrm{R}$., op. cit., p. 40. 
Uma vez estabelecida a relação, a questão fundamental é de ir além do simples passar de um lado a outro da relação, isto é, de considerar a relação não apenas, como até agora, a partir dos relacionados, mas em si mesma. Em Hegel, isto significaria, segundo Bubner, a passagem da simples oposição para a contradição. Como é possivel isto? Certamente não assumindo uma falsa metafísica afirmando que toda a realidade é perpassada por contradições, pois isto pressupōe uma confusão grosseira entre lógica e realidade e, além disto, nada tem de dialético.

No entanto, esta reviravolta que faz de uma oposiçăo uma contradição é muito importante para Hegel, porque, aqui, se revela a diferença fundamental entre refiexăo e especulação. A reflexão estabelece uma relação entre uma determinidade, que constitui o começo e uma outra, que é pressuposta a fim de que a primeira possa ser. Através do vai e vem entre os relatos da relação, apenas, se encobre a situação de cisão, que domina. Chamá-la pelo nome é condição para que se possa chegar a uma unidade que até agora não emergiu. Explicitar o momento da unidade significa mostrar, claramente, que os lados são inconciliáveis, 0 que se torna possivel enquanto emergência de uma nova relação em relação à primeira: a primeira relação é um lado da nova e o outro lado é a unidade de ambas, o que ainda faltava na formação da primeira relação. Isto se faz, então, enquanto a primeira relação reflete sobre si mesma, ou seja, enquanto é relação da relaçăo. É, precisamente, isto que constitui a virada que dá vida ao processo dialético e, aqui, a relaçâo, reflexivamente, estabelecida, é, unicamente, relativizada em função daquilo que, da fato, desde sempre, é pretendido por ela, mas não é efetivado, a saber, a unidade da coisa.

Como se fundamenta esta passagem da reflexão para a especulação? Ao invés de vincular os dois lados de uma coisa dada, precisa a reflexão, que se eleva à especulaçăo, pôr-se em relação àquela coisa e, assim, já se estabelece a relação complexa a partir dos componentes presentes. Por que isto, exatamente, neste lugar do processo? Aqui um retorno a Platão é, segundo Bubner, fundamental, pois os instrumentos literários de exposição săo, metodologicamente, mais importantes do que o purismo de um desenvolvimento conceitual puro quer reconhecer. Eles constituem a forma de que dispõe Platåo para, no prosseguimento do diálogo, urgir a lembrança necessária da coisa contra a reflexăo que se propaga. Eles marcam, assim, em pontos essenciais, a reviravolta dialética. Em que lugar do diálogo isto deve ocorrer é impossivel estabelecer a partir de um método lógico, pois nenhuma regra especulativa se aplica, sem mais, a casos do diálogo, mesmo que se tenha que dizer que está presente, no desenvolvimento do diálogo, uma lógica interna do progressivo esclarecimento de uma coisa.

Para Bubner, é indispensável, para que se possa entender a reviravolta, considerar seu oposto, ou seja, a estabilidade provisória, pois é, aqui, que se deve mostrar que permanece ainda não realizada a intenção que levou a um engajamento com o processo, o que vai, então, tornar manifesto que a reviravolta é menos um enigma procedimental do que um esclarecimento de conteúdo, já que o que, aqui, é fundamental, é a aproximação à coisa em questão a fim de que se possa mostrar que as propostas de solução, até agora, ainda, falham. Não se trata, então, de tornar mais denso ainda o trabalho da reflexão, mas de fazê-lo transparente, o que, só, a própria reflexăo pode conseguir. 
Como estímulo pode servir, sobretudo, uma objeção formulada em relação ao conteúdo, que corrige a segurança formal do procedimento. Uma insatisfação se manifesta e torna plausível que, assim, não se vai adiante e, desta forma, se faz necessária a reviravolta. Para Platäo, ${ }^{28}$ chegando-se a este ponto, efetiva-se a reviravolta inesperada na base de inovaçōes de conteúdo, que são introduzidas sem preparação sistemática. Trata-se, sempre, de um saber a mais: o estimulo para a superação do status quo do diálogo se faz em nome de uma deficiência de conteúdo. O novo saber alarga o horizonte anterior e, só, lentamente, os dialogantes conseguem apropriar-se dele. Numa palavra, nos pontos críticos do diálogo, confirma-se uma capacidade de aprendizagem de conteúdo, que se funda, em última instância no fato de que o novo não é, de fato novo, mas pertence ao horizonte total do problema em questão: o diálogo produtivo e a reflexão esclarecedora se fundam na grandeza transcendental de um pré-saber latente, que aguarda seu despertar metódico.

\subsection{3 - A Dialética enquanto alternativa à demonstração estrita}

Aristóteles trabalhou o conceito de Tópica, em contraposição ao conceito de dialética de seu mestre Platão, na medida em que perguntou pelo fundo a partir de onde se gera o método universal do diálogo. No Organon sảo tratados juntos Dialética e Analítica, enquanto ambos dizem respeito a silogismos: a analítica decompõe silogismos e demonstraçōes cientificas em seus componentes, enquanto que a dialética tem a ver com o ato retórico da persuasăo. A diferença diz respeito, acima de tudo, às premissas: a analitica tem a ver com premissas vinculantes, que se sustentam em fundamentos verdadeiros dos quais podem ser deduzidos outros $\mathrm{co}$ nhecimentos. A dialética tem a ver, apenas, com a persuasão do público: trata-se de silogismos com a pretensão reduzida do provável, cujas premissas não são isentas de dúvidas. Uma prova cientifica pressupōe, então, fundamentos seguros que estāo para além da variedade de opiniões e se fundam na evidência da razão. É a própria razão que garante a segurança destes fundamentos, pois, do contrário, cairiamos num regresso ao infinito sem que demonstração alguma fosse possível.

Os fundamentos da dialética não existem, já, firmes, mas devem, ainda, ser descobertos. Daí porque é tão importante, na retórica, a descoberta de argumen. tos. A Pragmática Transcendental difundiu a falsa idéia de que, onde se fala, se argumenta. Na verdade, argumentos se fazem necessários quando há disputa a respeito de questões: é quando um proferimento se revela como uma simples tese, que precisa de sustentaçăo argumentativa. Portanto, a argumentação começa ali, onde a validade de uma tese é contestada, o parceiro exige uma fundamentação, o dar a razão de. O sucesso depende da capacidade divinatória de chegar ao argumento adequado e o conflito termina, aí, onde se nomeia algo comum que, para além da oposição originária, vincula os parceiros. Só vale, então, como argumento aquilo que não é, de novo, a expressão de uma perspectiva particular, que provocaria quaisquer alternativas. Na realidade, diz-se um outro, mas é o mesmo que é dito, pois o novo é o velho, mas situado, agora, na esfera da universalidade a que todos podem ter acesso.

28 Cf: Bubner R., op. cit., p. 56 . 
Por esta razâo, uma argumentação bem sucedida tem relevância social, já que se gera um acordo à luz do universal em que todos participam até que ele seja revidado, pois uma adesåo coletiva pode, perfeitamente, radicar-se numa ilusẫo. ${ }^{29}$ Sobre isto não se pode ter, no seio da dialética, nenhum juizo definitivo, pois, do contrário, estariamos abandonando a dialética e entrando na esfera da analítica, ou seja, nos procedimentos das demonstraçōes rigorosas, onde o que está em jogo é uma deduçăo do particular a partir do universal ou do caso a partir da regra.

Com isto, contudo, não se deve confundir adesão a argumento com compromisso, pois o que, aqui, está em questão é a utilidade prática numa avaliação de interesses. A argumentaçăo se distingue tanto do compromisso como da demonstração estrita, uma vez que nela nós dispomos de principios a partir de onde as deduções são feitas, enquanto, na argumentaçăo, o fundamental é a busca de princípios e, assim, ela é retorno ao que ainda não se tem. A Tópica é, exatamente, esta busca dos lugares lógicos a partir de onde se podem derivar conhecimentos. Os tópoi são universalidades, cuja função é pôr fim aos conflitos e na medida em que eles não existem, simplesmente, como algo já firme e fixo, estão abertos à confirmação. Portanto, eles abrem possibilidades, para as quais se devem buscar argumentos e, de forma alguma são fundamentos a partir dos quais podem ser oferecidas explicaçōes científicas para os fenômenos da natureza ou da sociedade.

Neste sentido, a arte de argumentar constitui, para Bubner, o método próprio da filosofia na medida em que o que caracteriza a pergunta filosófica é que não hả receitas prontas para suas perguntas. Tudo, em princípio, pode ser posto, radicalmente, em questão, o que leva a uma situaçăo de insegurança, da qual, somente, a demonstração argumentativa de um campo de possiveis convicçőes partilhadas nos pode fazer sair. Para tudo existe um horizonte último de compreensão. 0 espaço deste horizonte é o espaço da linguagem, pois o que fazemos valer, argumentativamente, uns diante dos outros, é o que nos é conhecido, elementarmente, enquanto falantes. $\mathrm{O}$ ordenamento lingüístico contém, em suas potencialidades atemáticas, anteriormente a qualquer reflexão, os possiveis pontos de vista e as perspectivas, que, eventualmente, se deixam transformar em argumentos.

Os lugares da tópica designam algo como categorias imanentes à linguagem, que não conhecemos ainda, mas que podemos aceitar, quando nos são oferecidos argumentativamente, porque, em princípio, já sempre, temos familiaridade com sua função ordenadora. Bubner distingue entre categorias, no sentido estrito, e tópoi, já que as categorias constituem o quadro básico de nossa fala objetiva, sobretudo científica, que têm a finalidade de chegar a uma determinação fundamental e abrangente da realidade. Mas para os que acham que toda nossa linguagem é objetiva, as categorias constituem, entăo, as únicas perspectivas relevantes sob as quais, quem fala, tem que considerar seu objeto. A tópica, alarga, entäo, enormemente, o campo da linguagem humana, embora de nenhuma forma ela pretenda apresenta uma espécie de teoria retórica das idéias, nem também oferece para o diálogo um mínimo de sentenças básicas de relevância ontológica. A dialética, entăo, em sua articulaçăo tópica, não faz outra coisa do que conceptualizar uma racionalidade radicada no mundo vivido sem, com isto, imitar os procedimentos científicos. 


\section{2-A Dialética enquanto método de uma metafisica transcendentalmente fundada}

\section{1 - D. Wandschneider e a Dialética enquanto Lógica. Fundamental}

\subsection{1 - Lógica Dialética enquanto programa de auto-fundamentação da Lógica}

D. Wandschneider parte da afirmação de que a pergunta que D. Henrich levantou, há uma década e meia - que é dialética? - ainda permanece sem resposta. A grande tarefa desta discussão consiste, hoje, então, acima de tudo, em conseguir clareza sobre o rigor e a aceitabilidade da argumentação dialética, ou seja, trata-se, antes de mais nada, de articular uma teoria da dialética enquanto procedimento argumentativo, portanto, enquanto problema lógico. A intenção básica de Wandschneider é de cumprir esta tarefa, ou seja, de explicitar as estruturas básicas da argumentação dialética a partir de uma reflexão sobre as condições necessárias da argumentação, portanto, enquanto lógica fundamental..$^{30} \mathrm{~A}$ dialética é, entâo, uma explicação sistemática da lógica fundamental, ${ }^{31}$ ou seja, o procedimento dialético tematiza, sucessivamente, condiçōes, categoricamente, necessárias de sentido da argumentação e explicita suas relaçōes de principiamento.

O primeiro problema que exige um esclarecimento é que, como veremos, o procedimento dialético é, em principio, um procedimento apriórico, que se utiliza, essencialmente, de instrumentos lógicos: principios lógicos (o princípio de năocontradição, o princípio de complementariedade), estruturas básicas lógico-formais (relaçōes de dedução) e categorias lógicas (ser determinado, relação, etc). A pretensão da dialética é, precisamente, de reconstruir estes meios, ${ }^{32}$ aqui, antes de mais nada, enquanto teoria do desenvolvimento conceitual, que deveria completar-se com uma teoria das estruturas formais básicas e dos princípios lógicos. Portanto, a lógica dialética é uma auto-reconstrução da lógica, que torna visivel, com seus próprios meios, o que ela mesma é.

30 Toda filosofia pressupōe a possibilidade de argumentaçåo e com isto a lógica, mesmo aquela que faz da lógica seu princípio. A lógica, portanto, pressupõe a si mesma e, só, pressupōe lógica. Por isto toda fundamentaçäo da lógica, só, pode ocorrer no selo de si mesma. Cf.: Wandschneider D. Grundzüge einer Theorie der Dialektik. Rekonstruktion und Revision dialektischer Kategorienentwiclung in Hegels "Wissenschaft de Logik", Stuttgart, 1995.

31 Segundo Wandschneider, Hegel mostrou que, somente, o Lógico-Ideal pode ser considerado o principio absoluto e sua absolutidade deve ser demonstrada e, conceptualmente, expressa. Na medida em que ele atribui ao Lógico absolutidade, Este nảo pode ser, apenas, um principio subjetivo de pensamento, mas deve valer, objetivamente, num sentido quase-platônico. Um tal LógicoIdeal é, entảo, principio ontológico transubjetivo, portanto, o Lógico é, ontologicamente, fundamental, principto fundamental de todo e qualquer ser.. Cf.: Wandschneider D., Grundztige, op. cit. p. 13-14.

Para Wandschneider, nos sistemas formalizados, permanecem não tematizadas determinadas relaçōes: interdependências do ponto de vista de uma teoria de principios, conexões de principiamento a nivel de conteúdo, que apontam na direçăo de uma infra-estrutura conceitual sob a superficie das vinculaçōes formais. Cf.: Wandschneider D., Raum, Zeit, Relativität. Grundbestimmungen der Physik in der Perpsektive der Hegelschen Naturphilosophie, Frankfurt am Main, 1982, p. 11. 
Neste procedimento, a dedução das categorias fundamentais se deve pôr no começo, pois para poder caracterizar as estruturas lógico-formais ou os principios lógicos já devem estar à đisposição conceitos mais altos como, por exemplo, sentença, predicado, premissa, princípio formal, etc., para cuja reconstrução săo pressupostos os conceitos elementares (diferença, relação, ser determinado, etc.). Por fim, o próprio procedimento de argumentação deve ser justificado no contexto de uma auto-reconstrução da lógica, pois não se trata, aqui, de uma argumentação qualquer, mas daquela que atribui aos componentes da lógica seu lugar no seio da lógica. ${ }^{30}$ Este procedimento para poder operar pressupõe toda a lógica e ele mesmo nada mais é do que uma explicitação e fundamentação do que é pressuposto.

Que a lógica se reconstrói a si mesma, significa dizer que ela tematiza suas condiçōes de sentido e validade, ou seja, não se trata, aqui, simplesmente, de construtos formais convencionais, ${ }^{34}$ que podem ser substituidos por outros, mas de condiçōes fundamentais de toda e qualquer argumentação, numa palavra, daquilo que toda argumentação, necessariamente, pressupõe e por esta razão não pode ser eliminado argumentativamente..$^{35}$ Seus princípios, portanto, não estăo a nosso dispor: não estou livre, pensando, de me decidir pala lógica ou não.

Uma primeira conseqüência desta reflexão: tratando-se de condições aprióricas de possibilidade da argumentaçăo enquanto tal, ou seja, de condições transcendentais, elas sāo, simplesmente, inelimináveis, já que a tentativa de refutá-las pressupōe a possibilidade de argumentar e com isto se tem que aceitar 0 que se pretende refutar, ou seja, elas são condiçöes necessárias de sua própria negação e, por outro lado, näo podem ser demonstradas, dedutivamente, sem petitio principii,

33 Certamente, há muitas "lógicas". Todas elas, enquanto constrų̧óes lingüísticas, contêm elementos convencionais aos quaís năo se pode atribuir caráter transcendental. Mas, para Wandschneider, todas elas, sempre, pressupōem principios categóricos como o principio de năo-contradiçăo, pois sem isto elas seriam, em última instảncia, formaçōes destituidas de qualquer sentido. $\hat{\mathrm{B}}$, justamente, aquí que se pôe a pergunta pelas estruturas conctetas de uma tal lógica fundamental categoricamente válida.

34 O processo dialêtico de desenvolvimento conceitual difere, profundamente, segundo Wandischneider, de um sistema formal. Bm contraposição à multiplicidade de determinaçōes formais fixas, que, de antemăo, são portadoras de uma interpretação definida $\mathrm{e}$, só, são associáveis de acordo com regras estabelecidas, no processo dialético efetiva-se uma conexăo de fundamentação de conceitos, que so, aqui, se produz argumentativamente. Precisamente neste processo se desvela uma estrutura conceitual antes oculta e com isto ele efetiva uma espécie de reconstruçáo racional da coisa. Cf.: Wandschneider D., Raum, Zeit, Relativität, op. cit., p. 12.

35 Para Puntel, a questảo, aqui, parece nẩo ser, apenas, a da possibilidade de uma reconstruçäo logico-formal do procedimento dialético, pressupondo-se uma relaçăo positiva entre dialética e lógica formal, mas vai mais longe no sentido de dizer que qualquer procedimento pressupde uma semântica e, assim, um conceito de inferència com que implicitamente se trabalha, portanto, uma lógica. Existe, entåo, uma logica fundamental? Qual seria o procedimento de sua reconstruçăo? 0 problema serla, entâo, o da reconstruçăo lógico-formal deste procedimento ou antes da própria auto-fundamentaçăo da lógica? Não há, aqui, um profundo mal-entendido nesta discussăo com Wandschneider no sentido de que, talvez, os dois falem, pelo menos a nível do explicito, de coisas distintas: para Wandschneider o problema é o da auto-fundamentação da lógica, que é anterior ao problema das construçöes convencionais da lógica formal; para Puntel, trata-se de se perguntar como é possivel formular, num contexto lógico-formal, o procedimento dialético. Dai sua tese: nos très possiveis contextos de reconstruçăo lógico-formal do procedimento de Wandschneider, ele se revela, logicamente, insustentável. Cf.: Puntel, L.B, Dialektik und Formalisjerung. Discussion (mimeo), München, 1997. 
já que são, necessariamente, pressupostas por qualquer demonstração. ${ }^{36}$ Neste caso da reflexão transcendental, o círculo de fundamentação é inevitável, ele é um circulo necessário. Numa palavra, existe um cerne de estruturas lógicas fundamentais, que, enquanto condições transcendentais da argumentação enquanto tal, são inelimináveis" e constituem o que Wandschneider denomina a "Lógica Fundamental" que, enquanto tal, é autônoma, isto é, ela nem pode ser fundamentada por uma lógica mais fundamental, nem por uma instância extra-lógica. Neste sentido, ela não pode ter fundamento fora de si mesma e, portanto, tem que se fundamentar a si mesma, assim que a auto-reconstrução dialética da lógica é, ao mesmo tempo, sua auto-fundamentação. A lógica, só, pressupỏe lógica para sua fundamentação e, precisamente, neste sentido, deve ser denominada "sem pressupostos".

\subsection{2 - A Teoria do Desenvolvimento Conceitual}

\subsubsection{1 - A Sintese entre aposterioridade das categorias e a aprioridade do procedimento reconstrutivo}

Uma questão primeira e fundamental é de onde a dialética consegue suas categorias. Para Wandischneider a resposta è clara: elas provêm da linguagem empirica, o que significa dizer que a dialética não gera categorias novas, conteúdos significativos novos. ${ }^{30} \mathrm{O}$ conteúdo das categorias é, assim, pressuposto pelo procedimento dialético. A partir daqui surgem duas outras questōes: primeiro, em que sentido se pode, então, falar de desenvolvimento conceitual se os conceitos são tomados da linguagem já conhecida. Por outro lado, em segundo lugar, como fica o rigor de tal procedimento dado o caráter empirico das determinações.

O procedimento dialético de auto-reconstruçăo da lógica parte, entåo, de duas pressuposiçōes básicas: toda a lógica, do contrário seria impossivel argu-

36 Wandschneider vẽ este tipo de argumentaçăo, fundamentalmente, já, presente no Sofista de Platăo e, na atualidade, sobretudo, na Pragmática Transcendental de K-O Apel, porém, com uma diferença básica: em Apel, recorre-se à ineliminabilidace da linguagem, enquanto que, aquu, tudo se radica na logica emaranhada na linguagem. Cf.: Wandschneider D., Grundzüge, op. cit. p. 18.

Precisamente, aqui, me parece está a questảo central, nesta discussảo, sobre o lugar da lógica formal na fllosofia. Enquanto que, para Wandschneider, toda articulação lógico-formal pressupōe as condiçōes aprióricas inelimináveis da argumentaçäo enquanto tal, para Puntel a formalização nẫo pressupōe nada, porque é por meio dela que qualquer compreensão é articulada. Formalização, segundio sua compreensăo, é a indicaçăo da forma, ou seja, nada mais do que a exposiçāo exata da estrutura própria, detalhada, tanto da forma de dizer como do dito. Neste contexto, năo tem qualquer sentido ainda falar-se de "compreensão pressuposta", uma vez que, só, se sabe com precisão de que compreensẫo, realmente, se trata na medida em que ocorre uma formalizaçăo. A formalizaçåo é, entåo, a forma suprema de articulaçăo do que seja compreensão, explicaçẩo, etc. Assim, a formalizaçăo não é algo secundário, posterior, o luxo, de que seria possivel prescindír, já que a coisa em questão serla independente dela, mas, ao contrário o esquema ou a forma apresenta, precisamente, a estrutura exata da predicaçăo já sempre compreendida. Cf.: Puntel L. B., Dialektik und Formalisierung, op. cit. p. 11-12.

38 Wandschneider se liga, aquí, à posiçăo de $\mathrm{K}$. Hartmann para quem a dialética não é decução de conteúdos, mas reconstrução do conhecido, mas, justamente, na ordem da compreensăo. Ela é, portanto, a genealogia das categorias já sempre empregadas, a racionalizaçăo do encontrado. Cf: Hartmann K., Zur neuesten Dialektik-Kritik, in: Archiv f. Gesch. der Philosophie, v. 55, 1973, p. 227-229. 
mentar, e a linguagem fático-empírica e suas significações. Neste sentido, desenvolvimento conceitual, só, pode significar explicação dos meios lógico-semânticos, já sempre, pressupostos, ou seja, como explicação sucessiva das próprias pressuposiçōes da lógica e desenvolvimento significa, especificamente, a apresentação de conexões de "principiamento", ou seja, trata-se de mostrar uma sequêencia fundamentada e bem ordenada de categorias de tal modo que cada uma delas seja principiada pelas categorias antecedentes e é, somente, neste sentido estrito que se pode dizer que o procedimento constrói significaçōes, isto é, partindo da categoria mais pobre em conteúdo, do ser e de sua negaçăo, ele vai construindo conteúdos de significaçăo na base das significaçōes, já, respectivamente, construidas com o objetivo de mostrar as estruturas de principiamento. As significações são, assim, passo a passo, construidas, mas, na realidade, se trata de uma reconstrução justamente enquanto explicitação das conexões de significações.

Que função têm os conceitos empiricos neste procedimento? Simplesmente a de reproduzir, de forma aproximada, as significações construidas de forma procedimental. ${ }^{39}$ Se eles correspondem adequadamente ou não a esta condição, deve ser testado através de um retorno ao procedimento. Se um determinado conceito empírico cumpre melhor esta tarefa do que outro não é uma questão interna ao procedimento, pois se trata de uma questão do uso empírico de conceitos. O procedimento em si mesmo tem função normativa independentemente destas questŏes empíricas.

Nesta perspectiva, o procedimento dialético de desenvolvimento conceitual é, em principio, estritamente apriórico: ele é, certamente, independente, das oscilaçōes empíricas de significaçăo, porque é normativo-construtivo, ou seja, desenvolve significações, sucessivamente, umas das outras e, com isto, prescreve, ao mesmo tempo, seu conteúdo de sentido. A introdução de categorias empíricas serve, exclusivamente, à compreensão aproximativa, o que permanece testável através de critérios procedimentais. Que o procedimento, em principio, seja dotado de rigor, de modo algum significa para Wandschneider que ele não tenha dificuldades.

\subsubsection{2 - A estratégia argumentativa}

Qual deve ser o começo, ou seja, qual seria a condição mais elementar de sentido da argumentação? Para Wandschneider é a proposição que está vinculada a toda e qualquer sentença, que algo é o caso. ${ }^{40}$ Este "ser o caso" é interpretado por Wandschneider como um ser predicativo e, neste sentido, ele nada mais é do que a forma imediata de pretensão de verdade de sentenças. Em seu sentido posi-

39 Cf.: Wandschneider D., Grundzüge, op. cit., p. 184-185.

40 Wandischneider vincula-se, aqui, à posição de J. Burdidge, que caracteriza esta postura assim; dizemos que algo é determinado. Se abstraimas da determinaçăo só nos resta o "é" e este enquanto verbo de auxilio, é incompleto e aberto a determinaçő́cs. Numa palavra, no comoço, nada determinado pode ser pressuposto a năo ser a condiçăo de possibilidade de determinaçăo e isto é a forma da predicaçăo no sentido der "ser o caso". O sentido de ser é relação a determinidade. No contexto da logica, ser é, primariamente, entendido como um ser lógico e por isto a ser interpretado predicativamente como "ser o caso" Ct.: Burdidge J., On Hegel's Logic. Fragments of a Commontary. Atlantic Highlands, N. J., 1981, p. 38. Wandschneider D., Zur Struktur dialektischer Begriffsentwicklung, in: Wandschneider D. (ed.), Das Problem der Dialektik, Bonn, 1997, p. 118-119. 
tivo, já, está, sempre, presente a delimitação contra o que ser não significa, isto é, contra seu oposto "não ser o caso" ser" é co-posto, isto, é a delimitação é constitutiva para a significaçăo. Ê fundamental, portanto, esta oposição básica entre proposição e negaçăo. ${ }^{42}$ Isto motiva a introdução das categorias correspondentes: Ser e Não-ser.

Wandschneider interpreta, terminologicamente, esta oposição complementar enquanto a "Diairesis" platônica como a introduçăo de determinaçōes complementares, ou seja, enquanto "principio de complementariedade": o positivo, jả, é, sempre, contaminado com negatividade. Para Wandschneider, as oposiçōes complementares nem podem ser contraditórias (como exemplo vermelho e nãovermelho no sentido de tudo mais), pois neste caso elas preencheriam, sempre, todo o universo lógico, enquanto que as oposiçōes complementares podem ocorrer numa parte deste universo; nem, também, contrárias, porque os contrários admitem degraus intermediários (por exemplo, degraus de cinzento entre branco e preto).

De acordo com o principio de complementariedade Ser é, semanticamente, equivalente a năo-Não-ser: “ $S$ " = "não- $N$ " (1).43

Com isto se faz, antes de mais nada, valer a contraposição complementar entre Ser e Năo-ser. Esta relação de oposição pertence, constitutivamente, ao sentido do ser de acordo com o princípio de complementariedade. Assim, vale, também, que " $\mathrm{S}$ " não é equivalente a "N" e este "não é" mostra que o próprio conceito "S" representa um caso de "Não-ser", ou seja, que ele possui aquela qualidade, que corresponde à significaçăo de "Não-ser" e, desta forma, é ele, também, uma instância de "Não-ser", o que se exprime na fórmula: " $S$ " é correspondente a "Não-ser" (2).

Que uma entidade é correspondente ao conceito "N", ou seja, é uma instância do mesmo, pode-se exprimir, platonicamente, dizendo que a entidade participa na idéia "N", ou, simplesmente, que ela tem a propriedade "N".

No entanto, não se pode permanecer na sentença (2), pois o "é" que aparece nela exprime de novo um ser assim que a "S" agora se tem que atribuir aquela propriedade, que corresponde à significaçăo do próprio conceito de "Ser", isto é, "S" não é correspondente a " $N$ " (3).

41 Não se pode começar com uma negação, como é sugerido pela abstração de toda determinação, porque a negaçăo, em última instáncia só tẹ sentido enquanto negaçăo de um positivo pressuposto, ou seja, o sentido de Näo-A pressupỏe o sentido de A, o que revela que o negativo, já, é, sempre, mediado. Para Wandschneider isto se exprime melhot com a categoria Năo-ser do que, como queria Hegel, com a categoria Nada. Cf.: Wandschneider D., Zur Struktur, op. cit., p. 119. 120 .

42 Vem de D. Henrich, no debate contemporâneo, a compreensăo do papel fundamental que, na dialética exerce a negaçắo. Cf. sobretudo, Henrich D., Formen der Negation in Hogels Logik, in: Horstmann R-P., Seminar: Dialektik in der Philosophie Hegels, Frankfurt am Main, 1978, p. 213229.

43 Com esta distínçăo entre sentido pcsitivo e negativo da sentença, o principio de não-contradiçăo, jâ, está, implicitamente, ativo, embora neste nivel ainda não estejam à disposiçāo os mejos categorlais para sua formulação. De fato, a argumentação, só, é possivivel se se pode distinguir entre o que é o caso e o que não é o caso e é por isto que as categorias ser e não-ser sâo fundamentais. Cf.: Wandschneider D., Letzbegründung und Logik, in: Klein H-D., Letzbegründung als System?, Bonn, 1994, p. 84-103. 
Na base deste não é, é "S" de novo não correspondente a "N" e, sucessivamente, ou seja, à categoria "S" são atribuidos, alternadamente, predicados contraditórios, o que significa, para Wandschneider, que, aqui, se trata, claramente, de uma estrutura antinômica. ${ }^{44}$

Para ele é de fundamental importância que se tenha bem presente que tipo de procedimento está, aqui, em jogo. De nenhuma forma se trata de uma dedução formal calculista, mas de uma argumentação que é fundamentada quanto a seu conteúdo: através da reflexão sobre a predicação de correspondência, respectivamente, efetivada, torna-se visivel um novo conteúdo, que é exprimivel em categorias através da mediação das determinações contrapostas subjacentes "Ser" e "Não-ser" e, assim, sucessivamente, dá oportunidade para uma nova predicaçẫo de correspondência. Numa palavra, a argumentaçăo consiste na gestação de estruturas reflexivas.

Revela-se, assim, uma estrutura antinômica de predicação a partir da qual se pode chegar a ao conceito antinômico que a ela subjaz e que tem a forma de: " $N$ " = não correspondente a " $N$ " (4). Neste momento se faz uma passagem fundamental: do nivel das propriedades para o nível da significação ("N"= não correspondente a "N"), que é uma consequêencia necessária da estrutura antinômica que está em jogo. Só que através da propriedade não correspondente a " $\mathrm{N}$ " é caracterizada a propriedade correspondente ao conceito "N", portanto, justamente a propriedade " $\mathrm{N}$ ". A isto corresponde, que o conceito "não correspondente a "N" é equivalente ao conceito "näo- $\mathrm{N}$ ", que, de acordo com (1) é de novo equivalente a "S". Então, o conceito antinômico conduz, finalmente, a: " $S$ " = " $N$ " (5).

Fundamental para a compreensão do desenvolvimento dialético de categorias é a passagem do nível das categorias para o nível da significação. Num primeiro momento, se trata de propriedades de correspondência da categoria " $\mathrm{S}$ ", quando se constata que ela é correspondente a " $\mathrm{N}$ " ou também não. Portanto, aqui nåo se trata, propriamente, de características de significação desta categoria, mas, simplesmente, de propriedades, que podem ser ditas dela, não de propriedades que ela mesma diz, isto é, significa. Precisamente através da demonstração da estrutura antinômica de tais determinaçōes é possivel retroceder ao conceito antinômico e, a partir daqui, ocorre uma extrema transformação a nivel da significação: Ser não é, agora, simplesmente, o oposto de Não-ser, é, também, equivalente a ele.

O resultado expresso em (5) é uma contradição com a premissa " $\mathrm{S}$ " = "não-N" formulada em (1). No entanto, esta premissa, em virtude do princípio de complementariedade, é ineliminável, pois ao sentido de ser pertence a delimitação contra sua negação. A contradição é, aqui, inevitável e uma consequiência da estrutura antinômica. Ela é de ordem semântica: ser deve ser equivalente no que diz respeito à significação com não-N e com $\mathrm{N}$, ou seja: ( $S$ " = "não- $N$ ") O ("S" = "N") (6).

44 Wandschneider continua, aqui,, aqui, a tradição recente de interpretara a lógica dialética como uma lógica antinômica. Cf.: Kulenkampt A, Antinomie und Dialektik. Zur Funktion des Widerspruchs in der Philosophie, Stuttgart, 1970. Kesselring Th, Die Produktivität der Antinomie. Hegels Dialektik im Lichte der gennetischen Erkenntnistheorie und der formalen Logik, Frankfurt am Main, 1984. Cf. tb.: Wandschneider D., Dialektik als antinomische Logik: Hegel Jahrbuch, 1991, 227-242; Das Antinomieproblem und seine prgamatische Dimension, in: Stachowiak H. (ed.), Pragmatik, v. IV, Hamburg 1993, p. 320-352. 
Há, aqui, a conjunçăo de duas sentenças que exprimem significações contrapostas de eqủivalência e o sinal 0 quer exprimir que os membros desta contradiçäo semântica são inseparáveis, o que significa dizer que não se trata, neste caso, de uma contradição normal, pois ambos os membros, apesar de contrapostos, têm que ser considerados como verdadeiros. Neste sentido deve-se dizer que a contradição antinômica é uma contradiçăo verdadeira, já que os membros, contraditoriamente, opostos se pertencem mutuamente. $\mathrm{O}$ que especifica a contradição antinômica, segundo Wandschneider, é que os membros da contradição pertencem a diferentes esferas de reflexão, portanto, se referem a aspectos diferenciados, que, num primeiro momento, permanecem ocultos. Eles se contradizem, apenas, aparentemente, por assim dizer, na base da falta de explicitação das possibilidades de diferenciação categorial.

O mecanismo fundamental para o aparecimento da contradição antinômica é o próprio conceito antinômico enquanto conceito negativo, semanticamente, autoreferencial. ${ }^{45}$ É exatamente a forma de negaçăo auto-referencial o mecanismo que é responsável pelo aparecimento de estruturas antinômicas. $\mathrm{O}$ caráter antinômico do conceito nos obriga a considerar os dois aspectos em questão como pertencentes, intrinsecamente, um ao outro, ou seja, como dois aspectos do mesmo estado de coisas. Wandschneider chama a contradição ${ }^{46}$ que emerge a nível da significação de contradiçăo dialético-semântica, que resulta da relação antínômica das determinaçōes opostas e por isto, em última instância, é contradição entre oposição e eqüivalência.

A argumentação dialética subjaz à contradição semântica, pois ela se movimenta no nivel das relaçōes de correspondência das categorias e conduz a uma permanente alternação de predicações. Este processo antinommico consiste em que cada predicação efetivada induz uma nova predicação, contraditoriamente contrapoșta a ela, de tal modo que cada predicaçăo é, através de si mesma, condição da predicação contraposta. Trata-se, aqui, neste nível, de uma contradiçăo dialéticopragmática. A contradição dialética tem, então, para Wandschneider, duas dimensōes inseparáveis: a contradição pragmática que, na medida em que implica uma alternação perene de predicaçōes, conduz a um processo dialético, portanto, exprime a dimensão dinâmica da contradição; por sua vez, a contradição semântica exprime o caráter estático na forma de uma ambivalência de significação formulada explicitamente. As duas dimensões da contradiçăo se efetivam em niveis diferenciados: a contradição pragmática no nível das propriedades das categorias, a contradição semântica no nivel da significação. Quanto à relação entre as duas

45 Trata-se, aqui, da especificidade dos conceitos negativos de relaçăo. Para Wandschneider, a correspondència de uma propriedade com um conceito apresenta, sempre, algo positivo, mesmo quando tanto 0 conceito de relaçăo como a propriedade a ele correspondente são negativos. Em relaçáo ao negativo, um negativo é idêntico, portanto, em correspondência positiva, um positivo, ao contrário, não- idêntico, assim, em correspondência negativa. Portanto, todo conceito, mesmo o negativo, é sempre, caracterizado, na base de sua normatividade, também, por positividade. No caso do conceito negativo, há, aqui, uma ambivalência de princípio: na base de seu conteúdo, ele tem um caráter negativo, na base de sua normatividade, um positivo. Bsta é a razão da ínversão de valor observada com o conceito negativo e isto é condiçăo da estrutura antinômica. Cf.: Wandschneider D., Grundzìge, op. cit., p. 33. 
dimensōes é importante lembrar que é a emergência da contradição no nivel das propriedades que torna possivel o retorno ao conceito antinômico que subjaz à argumentação dialética.

Precisamente através da contraposição de significação positiva e negativa induz-se uma afinidade entre as duas: em primeiro lugar, no nivel das propriedades das categorias e, depois, no nivel da significação. Através da contraposição entre Ser e Não-ser uma explicação deve ser dada. Para isto é necessário explicitar 0 que é pressuposto, ou seja, que Ser tem com isto, também, o caráter de Não-ser e, do mesmo modo, o de um Ser. Justamente isto é mostrado pela estrutura antinômica e é isto que leva à exigência de pensar estas categorias não só como contrapostas, mas, também, como equivalentes. Numa palavra, o antinômico, ou seja, o negativo auto-referido e, com isto, em si mesmo ambivalente, é o motor da formação dialética da síntese. Isto urge a introdução de uma nova categoria que corresponda a esta exigência e, assim, seja a síntese de contraposição e equỉivalência ${ }^{47}$

Para Wandschneider, portanto, a sintese não é, simplesmente, de conceitos contrapostos, por exemplo, Ser e Não-ser, mas ela é a vinculação de oposiçăo e equivalência, isto é, de relaçōes de conceitos na forma de sentenças contraditórias. A simples contraposição de duas determinaçōes não implica sua "superaçăo" num conceito superior. Somente a demonstraçăo, de que uma tal contraposição conduz a uma contradiçāo antinômica, explicita a necessidade da formação da sintese. Esta exigência se cumpre, certamente, pela categoria "ser-ai" (Dasein), pois, aqui, o Ser é, igualmente, Não-ser ou, inversamente, Năo-ser é Ser. Pode-se dizer, segundo Wandschneider, que a contradição antinômica obriga a introdução de uma categoria que envolve diferentes aspectos e, desta forma, consegue efetivar a exigência de síntese. Neste sentido, é, precisamente, a emergência da contradiçāo antinômica que torna compreensivel a necessidade de formação da sintese.

A categoria que emergiu como síntese "ser-ai" tem o sentido de Ser que, igualmente, é Não-ser. Esta nova forma de ser é, assim, marcada por um paradoxo de tal modo que a próxima exigência da reflexão é explicitar sob que condições uma tal determinação tem sentido. Que um Ser é, ao mesmo tempo Năo-ser significa que ele não é um outro Ser. Um tal Ser não seria mais, simplesmente, Ser enquanto tal, mas um Ser que é diferenciado, de alguma forma, em si mesmo e isto quer dizer que é determinado. Então, ser-aí no sentido de um ser que é, igualmente, não-ser interpreta-se como "ser-determinado" $\mathrm{O}$ passo explicativo exige, assim a introdução de uma nova categoria explicativa. Portanto, a explicaçãoo da categonia sintética ocorre através da indicação de suas condições de cumprimento e isto se faz na medida em que se realiza uma escolha, a partir da multiplicidade de pressuposiçōes implicitas, de uma categoria que, no lugar específico do desenvolvimento conceitual, é, necessariamente, pressuposta, isto é, aquilo que é, necessariamente, exígido, através do nível de desenvolvimento já atingido. Isto significa dizer que, no nível pragmático, isto é, aqui, na argumentação dialética que conduz à formação de síntese ser-determinado, já, sempre, ele está pressuposto, mas ainda não está, semanticamente, explicitado. Assim, as condiçōes de

47 Cf: Wandschneider D., Grundzüge, op. cit., p. 115 e ss. 
cumprimento não são inventadas, mas tematizadas porque estão implicitas na própria argumentação dialética. Portanto, a categoria explicativa, apenas, explicita o que, já, está, implicitamente, presente na categoria sintética enquanto suas condições ${ }^{48}$ A passagem, portanto, da categoria sintética para a categoria explicativa é a explicitação das condiçōes específicas do processo de formação da síntese. Neste sentido o procedimento dialético se revela como um empreendimento de recuperação reflexiva de suas próprias pressuposiçōes e de sua expressão categorial.

A condiçăo de cumprimento da exigência da sintese, só, pode ser, de acordo com a argumentação apresentada, a categoria de ser-determinado, porque, aqui, já, foi pressuposta uma diferença de ser: a diferença entre ser determinado de um modo e ser determinado de outro modo. Portanto, com a categoria serdeterminado está envolvida, igualmente, a contraposição entre ser assim e ser de outro modo. Esta contraposição corresponde à contraposição ser e não-ser de onde partiu o desenvolvimento dialético, o que revela que se trata de degraus análogos de desenvolvimento conceitual em diferentes niveis: a contraposição originária ser e não-ser conduz à síntese ser-aí.e à sua explicação serdeterminado, que, por sua vez, contém a contraposição ser assim e ser outro. Com isto temos um ciclo dialético completo isto é uma sequiência de passos (quatro) segundo os quais a argumentação se repete estruturalmente.

A diferença, já, latente na categoria explicativa é o fundamento do aparecimento de determinaçōes opostas complementares, que então são expressamente postas. Da funçăo de serem elas condiçōes de cumprimento da exigência de sintese se segue que as determinações opostas complementares săo excludentes, o que é uma exigência que, só, se determina, quando se exige que, só, existem duas de tais determinaçōes, o que, somente, é possivel quando as duas determinaçōes não, simplesmente, são excludentes, mas, além disto, complementares, ou seja, determinações que caracterizam um espaço lógico, que as duas preenchem plenamente.

Ora uma tal relação de duas determinações é dada, quando cada uma é definida como a negaçäo semântica da outra. Cada determinaçăo é, reciprocamente, o oposto da outra. Nesta caso não se trata, então, de uma negação absoluta, o que seria uma totalidade de significaçăo, totalmente, indeterminada que cobriria todo o universo semântico, mas de uma negação determinada, que é uma delimitação do universo semântico definida através de uma determinação universal. Através do conceito de fruta dá-se uma delimitação às diferentes espécies de fruta. No caso de determinaçōes opostas existe, certamente, uma tal determinaçāo universal, que efetiva uma delimitaçäo do universo semântico. Mas no caso de negação determinada a particularizaçăo do universal é determinada maximamente na medida em que este se diferencia no positivo, já pré-dado no universal e em seu complemento negativo. Somente sob a condição de uma tal relação de complementariedade de dois membros é inequívoca a particularização do universal. Só há, aqui, o estado positivo e sua negaçäo.

$48 \mathrm{Cf}$ : Wandschneider D, Grundzüge, op. cit., p. 122 ess. 
Tais considerações são, imediatamente, aplicáveis à relação entre determinação explicativa e determinaçōes opostas: a determinação explicativa funciona como o aspecto limitante universal $\mathrm{e}$ as determinaçöes opostas săo as particularizaçỏes e na medida em que elas estão na relação de negação uma para a outra, são complementares dicotomicamente. Assim, a única possibilidade de ter um espaço lógico com precisamente duas "espécies" é dado através das determinações complementares, que estão, uma em relação à outra, na relação de posição e negaçăo determinada. No caso, aqui, de um universal que particulariza a si mesmo, é afastada a contingência de acréscimo de particulares exteriores, pois o universal determina o particular, plenamente, a partir de si mesmo, ou seja, somente a partir de determinações complementares e isto, só, é possível na forma de negaçắo determinada. Um tal universal é o que Hegel denomina "concreto". Assim, o método dialético de desenvolvimento conceitual contém elementos do procedimento diairético, porém numa forma rigorosamente regrada, não-empírica, que exclui arbitrariedade.

A argumentação dialética consiste, então, em última instância, numa reflexăo transcendental sobre o que, já, sempre, se pressupõe com a contraposiçăo originária de Ser e Não-ser. Numa palavra, para Wandschneider, a Lógica Dialética é um procedimento, rigorosamente regrado, de reflexão transcendental $\mathrm{e}$, neste sentido, a forma de auto-explicação metódica da lógica fundamental. Ela não pressupōe, por isto, nenhum construto lógico específico, mas toma, simplesmente, as pressuposiçōes, transcendentalmente, necessárias, de sua própria argumentação para explicitá-las. Isto não é, portanto, uma lógica formal, mas uma lógica das categorias e dos principios lógicos fundamentais

\section{2 - Vitorio Hösle e a Dialética enquanto método adequado de exposição do Absoluto}

\subsection{1 - O programa do Idealismo Objetivo}

$\mathrm{O}$ acesso de $\mathrm{V}$. Hösle ao debate contemporâneo a respeito da dialética se faz, em primeiro lugar, através de sua tentativa de articular o programa filosófico que se gestou no idealismo alemão através do debate a respeito do pensamento transcendental, o que vai conduzir, em Hegel, ao idealismo objetivo, ou seja, a uma sintese entre metafisica e filosofia transcendental, ou a uma metafisica, ${ }^{19}$ transcendentalmente, mediada. ${ }^{50}$ Para Hegel, a filosofia transcendental chegou a um nível de criticidade, que não se pode mais eliminar. ${ }^{51} \mathrm{~A}$ tarefa da reflexão filosófica vai consistir em radicalizar esta postura, o que significa dizer conceber o princípio

49 Cf.: Fulda H. F., Philosophisches Denken in einer spekulativen Metaphysik, in: Patzold D./Vanderjagd A. (eds.), Hegels Transformation der Metaphysik, Köln, 1991, p. 62-82.

50 Cf.: Hosle V., Hegelssystem. Der Idealismus der Subjektivitát und das Problem der Intersubjektivitất, 2. vol., Hamburg, 1988.

51 Por esta razão, para Hösle, è necessário distinguir, com clareza, entre uma critica à fllosofia da subjetividade e uma critica à filosofia transcondental para a qual, do ponto de vista da fundamentaçăo, ele afirma nāo conhecer alternativa. Cf.: Hösle V., Intersubjektivität und Willensfreiheit in Fichtes "Sitteniehre" in: Philosophiegeschichte und objektiver Idealismus, München, 1996, p. 274, nota 25. 
básico da filosofia transcendental, o pensamento do pensamento, a autoreflexividade do pensamento, como princípio ontológico. ${ }^{52}$ A reflexăo transcendental conduz a um principio absoluto, que constitui tanto ser como pensar.

Hösle articula em quatro pontos básicos este programa de filosofia: ${ }^{53}$

a) Filosofia é, fundamentalmente, reflexão transcendental, isto é, reflexāo rigorosa sobre as próprias pretensōes de validade, isto é, fundamentação última do pensamento enquanto reflexão do pensamento sobre si mesmo e seus pressupostos inelimináveis. O princípio supremo desta filosofia é uma estrutura ineliminável, que se fundamenta a si mesma reflexivamente. ${ }^{54} \mathrm{O}$ pensamento do pensamento emerge, então, como o principio último de toda filosofia idealista. Esta reflexão não pode ser negada, pois qualquer negação a repōe: filosofia é, então, reflexão sobre o que não se pode negar, porque fundamento da própria negação.

b) O projeto de Fichte foi a primeira tentativa de superaçāo da forma de filosofia transcendental articulada por $\mathrm{Kant}^{65}$ e consiste, precisamente, em mostrar um princípio absoluto, ineliminável, de que não se pode duvidar. ${ }^{.6} \mathrm{~A}$ partir da validade absoluta deste princípio todo o sistema da filosofia ${ }^{57}$ deveria ser construido, ou seja, a partir dele deveriam ser fundamentadas todas as categorias básicas do pensar e do ser. Todo o sistema do pensamento humano depende, então, deste princípio ineliminável, cuja tematizaçăo é tarefa específica da filosofia, uma vez que as ciências particulares, enquanto axiomático-dedutivas, por definição, só, podem atingir uma validade hipotética. ${ }^{58}$ Para Hösle, o pensamento central e decisivo de Fichte é a descoberta da ineliminabilidade da razão, de sua absolutidade,

52 Para Hegel, uma filosofia transcendental radicalizada reconduz à concepçăo de ontologia pré-critca da metafisica moderna, porém, agora na base de um principio determinado que se fundamenta como subjetividade absoluta. Cf.: Hösle V., Hegelssystem, op. cit. p. 55. Cf.: Hösle V., Hegelssystem, op. cit. p. 52 e ss.

54 Nisto está, precisamente, o especifico da filosofia de Fichte: ela é uma filosofia reflexiva, o fundante e o fundado sẩo o mesmo, ou seja, o pensamento puro, que se capta a si mesmo. Frente à petitio principil de Kant, que sem dúvida pode ser negada consistentemente, existe, aqui, um circulo da ineliminabilidade, que é, radicaimente, diferente de uma petitio. Cf.: Hósle V., Die Transzendentalpragmatik, op. cit., p. 239.

55 A forma de fundamentaçăo transcendental articulada por Kant é, segundo Hőle, em muitos aspectos defeituosa. Antes de mais nada, Kant tem que, já, pressupor a possibilidade da experiẻn-

Àcia para poder fundamentar a validade das sentenças sintéticas a priori apesar de que são, fustamente, estas sentenças que tornam a experiência possivel(um circulo). Além disto, permanecem sem fundamentação as sentenças meta-transcendentais de Kant, como, por exemplo, que a intuição e a possibilidade da experiência constituem o "terceiro" a ligar sujeito e precicado. Cf.: Hösie V., Die Transzendentalpragmatik als Fichteanimus der Intersubjektivität, in: Zeitsch. f. phil. Forschung 40 (1986), p. 236-237.

A afirmaçảo básica de Fichte é que a inståncia fundante năo é mais a possibilidade da experiência, que, sempre, pode ser contestada e negada, mas o pensamento, o principio que, precisamente, é absoluto, porque nåo se pode ir além dele sem pressupó-lo. Cf.: Hósle V., Die Transzendentalpragmatik, op. cit., p. 237.

57 Fichte percebeu, claramente, que o método de fundamentaçāo através da reflexāo sobre o que não é negável, porque fundamento da própria negaçăo é, fundamentalmente, diferente do método das ciências particulares, que é o método da deduçăo de sentenças derivadas(teoremas) a partir de sentenças fundamentais (axiomas). Cf.: Hösie V., Die Transzendentalpragmatik, op. cit. p. 237.

O que significa dizer que elas, nunca, dizem algo de definitivo, pois sua pretensäo de verdade depende de premissas nâo-demonstradas. A aplicaçăo deste método à ética conduz ao nihilismo ético, já que as decisōes fundamentais sobre valores năo săo, racionalmente, fundamentáveis. Cf.: Höle V., Die Transzendentalpragmatik, op. cit., p. 241. 
de sua auto-fundamentação. Ora, sendo absoluto, este princípio nada pode ter contraposto a si, nada lhe estranho. Por isto, embora de acordo com o programa de Fichte - desenvolver uma filosofia a partir de um princípio absoluto - Hegel não vai concordar com sua efetivação, pois o segundo principio da "Doutrina da Ciência" se contrapõe à absolutidade do primeiro principio: um eu, que tem um não-eu contraposto a si, não pode ser o princípio absoluto. Numa palavra, o problema fundamental de Fichte é ter identificado o principio absoluto com a subjetividade finita. ${ }^{59}$ Se o princípio, enquanto estrutura reflexiva, é subjetividade, esta nảo pode ser uma subjetividade finita, mas, como diz Schelling, tem que ser unidade de subjetividade e objetividade, portanto, na linguagem de Hegel, Idéia, onde o momento da auto-reflexividade tem primazia.

c) A fundamentação última do pensamento apresenta uma estrutura lógicoideal, auto-reflexa e ineliminável, o Absoluto enquanto unidade de subjetividade e objetividade. Isto constituí, apenas, o começo da filosofia, que deve ser superado, porque a absolutidade desta estrutura, só, pode ser demonstrada, para Hegel, enquanto ela emerge como resultado de estruturas mais deficientes. $\hat{\mathrm{E}}$ indispensável, portanto, que a estrutura apresentada năo permaneça um ponto, que vale imediatamente e de onde tudo mais se segue, mas que se desenvolva na direção da totalidade das determinações lógicas, enquanto cosmos, processo, logicamente, estruturado de categorias. Todas elas constituem uma estrutura complexa e internamente diferenciada e, na medida em que são momentos da Idéia Absoluta, participam de seu caráter ontológico, isto é, são princípios tanto do espírito, como da natureza. Numa palavra, o Absoluto, só, pode ser fundamento absoluto, quando for possivel, a partir dele, explicar a realidade em sua diferenciação estrutural. Isto significa dizer que ontologia, enquanto teoria da estrutura inteligivel do real enquanto tal, e lógica, teoria do pensamento enquanto pensamento, portanto, enquanto teoria das categorias, são integradas enquanto metafisica, ${ }^{60}$ ou seja, teoria da estrutura absoluta, isto é, enquanto teologia racional, ${ }^{61}$ teoria categorial ${ }^{62}$ de Deus como o Absoluto, princípio subjacente a todo ente, o pressuposto enquanto tal por todo ato de pensamento, a suma de todas as verdades aprióricas, fundamento de todas as determinações, que nāo pode ser negado sem que seja pressuposto. Filosofia é, então, metafisica enquanto teoria das determinaçōes universais do ser e do pensar, portanto, conhecimento categorial do Absoluto, sintese entre o realismo ontológico e o idealismo subjetivo: tanto o ser como nossos pensamentos se regulam de acordo com a razão objetiva. Este é o caminho básico do idealismo objetivo segundo o qual as estruturas fundamentais do mundo e nosso pensamento podem estar de acordo, porque ambos säo principiados do pensamento

59 Cf.: Hegel G. W. F., Differenz des Fichte'schen und Schelling'schen Systems der Philosophic, Hamburg, 1962.

60 CI.: Fulda H. F., Spekulative Logik als "die eigentliche Metaphysik" - Zu Hegels Verwandlung des neuzeitlichen Metaphysikverständisses, in: Pätzold D./Vanderjagd A. (eds.), Hegels Transformation der Metaphysik, Koln, 1991, p. 9-27.

61 Cf.: Fulda H. F./Horstmann R. P./Theunissen M., Kritische Darstellung der Metaphysik. Bine Diskussion uber Hegels "Logik", Frankfurt am Mian, 1980.

62 Cf: Fulda H. F., Hegels Dialektik als Begniffsbewegung und Darstellungsweise, in: Horstmann R. P., Seminar, op. cit., p. 124-174. 
absoluto. As estruturas ideais, por um lado, são captadas a priori através do pensamento puro sem consideraçăo do ser empiricamente dado (momento idealista); por outro lado, precedem o espírito subjetivo, o qual, só, pode captá-las enquanto segue um método de fundamentação última enquanto método de autofundamentaçăo.

d) A idéla absoluta é tanto princípio das categorias lógicas como das categorias da filosofia do real. A realidade, só, pode ser conhecida porque ela é, estruturalmente, racional, ou seja, produto de uma razão objetiva: natureza e espírito são produtos da idéia absoluta e é por esta razão que a subjetividade finita pode captar, no mundo, as objetivações da razão. Em última instância, a realidade pode ser conhecida porque o Lógico-Ideal é seu fundamento.

A partir daqui se revela a tarefa especifica da filosofia: expor a Idéia Absoluta tanto na pureza da forma enquanto auto-fundamentação da lógica, quanto em sua efetivação no mundo objetivo da natureza e do espírito. Nesta perspectiva, Hegel leva adiante a posiçăo de Fichte de que é tarefa da filosofia fundamentar os princípios básicos e as pressuposições fundamentais das ciências particulares, o que permite à filosofia estabelecer uma ordem entre as ciências e superar o ser, puramente, fatual presente nas ciências particulares. Daqui porque o, especificamente, filosófico das disciplinas da filosofia do real consiste na mediação de seu conteúdo pela Idéia Absoluta.

Neste contexto, emerge uma questão fundamental: Hegel distingue entre o princípio da filosofia e sua exposição como sistema. Para isto a filosofia precisa das ciências particulares, que preparam o material para a filosofia na medida em que não permanecem no nível dos fenômenos sensíveis, mas os situam no nível de determinações universais, portanto, na esfera do pensamento. Esta dependência da filosofia em relação às ciências se dá no que diz respeito à gênese e, nunca, à validade dos conhecimentos filosóficos. Do ponto de vista da gênese, a mediação dos conhecimentos filosóficos através da experiência é irrenunciável ${ }^{63}$ Além disto, se a fllosofia do real parte da experiência, ela desemboca na experiência, pois é desejável que a filosofia apriórica do real busque, na experiência, a comprovação de suas teses uma vez que pertence à essência do real que ele não seja, só, conceito, mas que tenha um correspondente na experiência. Trata-se, aqui, de descobrir uma forma de tradução do conceptual na esfera das representações orientadas na experiência.

\subsection{2 - A Dialética enquanto método do sistema}

A filosofia se entende como teoria transcendental do Absoluto. Qual é a forma adequada de sua articulação? É neste contexto que se situa a pergunta pela dialética. $\mathrm{A}$ intuição básica do idealismo alemão é que a alternativa ao regresso ao infinito é um fundamento último que se mostra último por não poder ser eliminado de forma consistente, uma vez que se fundamenta, reflexivamente, a si mesmo. Este fundamento em Hegel, só, se explicita no fim de tal modo que ele pretende que a própria exposição da filosofia seja sua prova o que, aliás, só pode ser indi-

63 Cf: Hősle V., Hegelssystem, op. cit. p. 79 e ss. 
reta por duas razōes: a)A prova direta desemboca num regresso ao infinito ou numa ruptura dogmática; b)A prova direta se contrapỏe à natureza do Absoluto, pois o transformaria em algo dependente. Para Hösle é central para a compreensão da dialética explicitar a estrutura desta prova.

\subsubsection{1 - A demonstração negativa}

Para Hegel, o principio da filosofia é o pensamento do pensamento, ou seja, filosofia é retorno reflexivo do pensamento sobre si mesmo e, com isto, a demonstração de seu caráter ineliminável e, portanto, absoluto. No entanto, para Hösle, Hegel não trabalhou, com clareza, o argumento da ineliminabilidade da razão como alternativa para o regresso ao infinito, pois ele, só, o considerou como um momento de uma estrutura mais complexa, isto é, a da prova indireta da idéia absoluta.

Nāo há, propriamente, em Hegel, uma consideração explícita, a não ser no fim da lógica e de forma insuficiente, do que constitui o movimento próprio de articulação da filosofia hegeliana. Para Hösle nós nos podemos servir da crítica de Hegel à estrutura lógica das provas tradicionais da existência de Deus para uma reconstrução argumentativa da ciência da lógica. ${ }^{64}$

O problemático na forma das provas tradicionais da existência de Deus consiste, para Hegel, no fato de que elas fazem do ser necessário um ser dependente do finito. Ora, a especificidade do ser finito é ter um fim, passar, ser um ser que, só, tem o valor da possibilidade, tanto que é como não é. Para Hegel, a verdadeira estrutura da prova é outra, pois o contingente é contraditónio uma vez que não pode conservar-se fora do Absoluto. $\mathrm{O}$ argumento, então, deve ser transformado de tal maneira que o momento da negação, não tematizado na prova tradicional, seja, expressamente, posto: o finito é nada fora do Absoluto. Somente o Absoluto é o ser verdadeiro. Nesta perspectiva, o sentido da prova é a superação da própria mediação, pois aquilo através de que Deus poderia parecer mediado, o mundo, é declarado nada de tal forma que é o não-ser do mundo que é o caminho da elevação do espirito ao Absoluto. Assim, a prova cosmológica se transforma numa prova apagógica: o ser do Absoluto năo é derivado da pressuposiçăo da existência do finito, mas, antes, de sua auto-contradiçăo interna, de seu năo-ser. A lógica é a exposição ordenada destas determinaçōes através das quais o espírito se eleva ao Absoluto, portanto, ela é teologia metafisica.

Hegel principia esta exposição com a categoria menos determinada, uma vez que ela é pressuposta por todas as outras e vaí adiante através do mecanismo da negaçăo determinada. É, portanto, o momento da negatividade que gera a diferença e torna possivel a continuaçăo: cada categoria é seu conceito oposto, o qual, por isto, pertence, implicitamente, a ela. Este oposto, só, pode ser o contrário, que nega o conceito inicial permanecendo no mesmo nivel, enquanto que a indeterminidade do conceito contraditório permitiria todos os outros conceitos menos o negado.

64 Cf.: Hösle V., Hogelssystom, op. cit. p. 188 e ss. 
Numa palavra, é a seguinte a estrutura do método através de que se diz $\circ \mathrm{Ab}$ soluto: parte-se de uma determinaçāo, cuja contradição se mostra. Isto exige a introdução de uma nova categoria, que, só, pode ser sua negação determinada, seu oposto contránio ${ }^{65}$ Nesta se revela, também, uma contradição e, assim, sucessivamente, até que se chegue a uma determinação em que não mais seja possivel mostrar contradiçōes. Como se pode saber que a exposição categorial chega a uma conclusẩo? Para Hösle, segundo sua interpretação, contra Hegel, se a prova negativa é o único método de argumentação, então, nunca podemos saber, com segurança, se a categoria é, de fato, a última, pois uma contradiçāo, que ainda não foi detectada, pode estar latente. Numa palavra, para a razăo finita, a superação da contradiçăo, nunca, é definitiva e, por esta razão, se torna impossivel o fechamento do sistema o que, para Hösle, é, perfeitamente, compativel, com a fundamentaçăo última e, conseqüentemente, com a idéia de que filosofia é teoria do Absoluto. Nosso conhecimento do Absoluto não é absoluto, o que significa dizer que Hösle entende filosofia como síntese entre racionalidade forte e racionalidade fraca.

O mecanismo que vai fazer a exposição avançar é a descoberta de contradições. Para Hösle, trata-se, na dialética, de uma contradição pragmática entre o que é pressuposto pela categoria e o que é, explicitamente, expresso, portanto, de uma relação da categoria consigo mesma em dois niveis da linguagem humana: o semântico e o pragmático. Hösle se vincula, aqui, à concepção de W.Wieland, ${ }^{66}$ para quem todas as contradiçōes, na lógica, săo pragmáticas e, portanto, só, na Idéia absoluta há uma conclusăo, porque, somente, aqui, o conceito é o que visa: ele diz, explicitamente, o que, implicitamente, pressupõe.

O método, então, para detectar as contradições consiste na explicitação do implícito, pois o que está implícito é, pelo menos, parcialmente, explicitado pela nova categoria. Já que, então, a categoria suprema está presente nas contradições de todas as outras, devemos dizer que a idéia absoluta é a significação própria do ser, a primeira categoria. Daí a relação circular, em niveis diferentes, entre as primeiras e as últimas categorias: as primeiras são a pressuposição das últimas enquanto categorias a serem superadas e, por sua vez, dizem expressamente, o que as primeiras pressupõem. Numa palavra, todas as categorias se referem a um substrato comum, ainda indeterminado, o Absoluto, que, já, está, implicitamente, presente na pretensão de verdade da primeira categoria.

A manifestação da contradição, só, pode ocorrer, quando a categoria em questão se relaciona consigo mesma, o que levanta a objeção dos lógicos formais de que, aqui, emerge o risco da produção de antinomias. Para Hösle, as antinomias surgem de uma auto-relaçāo negativa e as categonias sintéticas na filosofia de Hegel, enquanto negação da negação, são categorias positivas. Hösle aceita, neste contexto, a idéia de $\mathrm{D}$. Henrich ${ }^{67}$ que a auto-relação negativa exerce um papel central no pensamento de Hegel, pois é o motor da prova negativa. No en-

65 Cf: Cirne Lima C. R. V., Dialética para principiantes, Porto Alegre, 1996.

67 Cf.: Henrich D., Formen der Negation in Hegels Logik, in: Horstmann R. P., op. cit. p. 213-229. 
tanto, é necessário acentuar que o momento negativo é central no movimento do conceito, mas, sobretudo, no caminho para seu resultado. Por isto mesmo, a antítese supõe a tese, já que o negativo supōe o positivo. A prioridade tem, por isto, o positivo, mas a categoria sintética, precisamente enquanto sintética, contém a negatividade, pois a integrou como seu momento.

\subsection{3 - A reformulaçăo hösliana do programa de uma filosofia transcendental absoluta}

Hösle procura reformular o programa hegeliano que, segundo ele, em sua execuçăo, é marcado por várias deficiências, atravês de um diảlogo com o pensamento contemporâneo, sobretudo, com a Pragmática Transcendental. ${ }^{68}$ Seu primeiro esforço vai consistir em reformular a prova indireta do sistema, antes de mais nada, esclarecendo seu objetivo: trata-se, simplesmente, da resposta à pergunta se todo conhecimento não-empirico é hipotético, ou seja, trata-se, aqui, exclusivamente da questão da validade de nossos conhecimentos e dos critérios de nossas ações o que, de nenhuma forma, elimina a questão da gênese do conhecimento fundamentado em última instância. A fundamentação última é central, em filosofia, porque, por exemplo, no campo da açăo humana, só, um conhecimento não-hipotético permite partir de um imperativo categórico, ou seja, de exigências incondicionais, que nos fornecem um critério para distinguir entre os fins legitimos e ilegitimos de nossas ações ${ }^{69} \mathrm{Em}$ contraposição à tradição (radicada em principios auto-evidentes), ${ }^{70} \mathrm{a}$ filosofia reflexiva chega, através da mediaçăo argumentativa, a algo incondicionado e é, por isto, síntese de imediatidade e mediação. Também no campo da razão teórica, só a fundamentação última permite, por um lado, mostrar como o cético, em sua criticidade, não é, suficientemente, radical e, por outro, que filosofia não é dogmatismo.

Para Hösle, o trilema de Münchhausen emerge como o grande contraargumento à fundamentação e, por esta razão, a confrontaçāo com ele é a forma mais adequada de explicitar a estrutura da prova de fundamentação. Trata-se de mostrar năo só que o argumento é auto-contraditório (contradição pragmática), mas que ele trabalha com um pressuposiçăo, na esfera da validade, que, de forma alguma, é necessária, a saber, que todo conhecimento não-empirico procede dedutiva-axiomaticamente, isto é, parte de axiomas nẫo-demonstrados. Claro que sob este pressuposto é impossível uma fundamentação última, o que manifesta que a tese do trilema é tautológica. Na filosofia, não se trata nem de deduçăo, nem de indução, mas de algo novo em relaçăo a ambos: sentenças fundamentadas, em última instância, sāo sentenças, cuja negaçāo é, pragmaticamente, contraditória e não podem ser demonstradas sem que sua validade seja pressuposta, ou seja, sua demonstraçăo se faz, indiretamente, através da auto-dissolução da posiçăo con-

68 Cf.: Hosle V., Die Krise der Gegenwart und die Verantwortung der Philosophie - Transzendentalpragmatik, Letzbegründung, Ethik, München, 1990.

69 Cf.: Hosle V., Moral und Politik. Grundlagen einer politischen Ethik für das 21. Jahrhundert, München, 1997.

70 Cf: Hosle V., Begründungsfragen des objektiven Idealismus, in: Köhler W. R./Kuhlmann W./Rohs, P. (eds.), Philosophie und Begründung, Frankfurt am Main, 1987, p. 212-267. 
traposta. O espirito da prova consiste, precisamente, em transcender o modelo axiomático de demonstração. A lógica formal é, como a matemática e todas as ciências fatuais, uma ciência hípotética que pressupõe tanto axiomas como regras de inferência e é, justamente, tarefa de uma reflexåo transcendental fundamentar estes axiomas e estas regras. ${ }^{71}$

O cerne do argumento de fundamentaçăo última consiste em demonstrar que existe algo que é condição de possibilidade de cada conhecimento com pretensão à verdade e isto precede todo conhecimento empirico. Por isto não se pode admitir a existência de um mundo que não fosse determinado pelas categorias implícitas na fundamentação última. A sentença: "Existe possivelmente algo que não podemos pensar" é, dialeticamente, auto-contraditória, pois, com isto, já, o estamos pensando. A partir daqui, se segue, sem que saiamos da imanência do pensamento, a afirmação básica do idealismo objetivo: a validade ontológica da prova de fundamentação última. Portanto, as categorias implícitas na fundamentação última valem para tudo o que é, mesmo que elas articulem, apenas, as condiçc̃es necessárias e não as condições suficientes de todo ente.

Para Hösle, o resultado mais importante da fundamentação última é que o idealismo objetivo se revela como a forma especifica da filosofia. No entanto, um idealismo objetivo que leva a sério o clima espiritual em que vivemos, hoje, não pode mais ter como metacategorias, apenas, o isto (objetividade) e o eu (subjetividade), mas tem que se confrontar, seriamente, com a questão da intersubjetividade. Isto traz consequiências para articulação da filosofia como sistema. Hösle fala de quatro mundos que, contudo, não devem ser entendidos como esferas, ontologicamente, irredutiveis, uma vez que as esferas reais - natureza, subjetividade e intersubjetividade - são manifestações da esfera ideal, do lógico. 0 espírito subjetivo se constrói sobre a natureza, o espirito intersubjetivo sobre a natureza e o espírito subjetivo. O confronto com a problemática da intersubjetividade, na filosofia contemporânea, conduz ao reconhecimento de que o Absoluto é intersubjetividade e de que a exigência ética última é a construçāo de um mundo intersubjetivo simétrico e transitivo. A unidade consigo mesmo, mediatizada por relações intersubjetivas positivas, isto é, simétricas e transitivas, é a tarefa suprema da vida humana, o sentido último do universo.

71 Cf. a última tomada de posição de Hösle em relação a esta questão em: Hösle V., Die Kriso der Gegenwart und die Verantwortung der Philosophie. Transzendentalpragmatik, Letzbegründung, Ethik, terc, ed., München, 1997, p. 276-279. 